\title{
Is School Lunch Connected to Literacy Achievement in Primary School Children? A South African Perspective Jace Pillay
}

South African Research Chair in Education and Care in Childhood, Faculty of Education, University of Johannesburg, South Africa

\begin{abstract}
This study investigated school lunch and achievements in literacy in a sample of South African primary school children. Data was collected through a quantitative survey administered with pupils $(\mathrm{N}=$ 160) from four grade 5 to 7 classes in a school in Soweto. The survey consisted of five literacy tests that were standardized by Do-It- Profiler, a UK based institute, and Shape the Learner, a South African based consultancy. Additionally, the survey included questions pertaining to the children taking lunch to school. The results show that learners who sometimes do not have lunch obtained statistically significantly lower marks on the combined learner profiler tests than learners who had some form of lunch provided. More specifically, learners who sometimes do not have lunch performed noticeably lower in the sound text, correct word, and most likely real word test. Based on social justice theory the author discusses the implications of the findings for literacy achievement in children who do not take lunch to school.
\end{abstract}

\section{Publication History:}

Received: January 17, 2017 Accepted: March 14, 2017

Published: March 16, 2017

\section{Keywords:}

Literacy achievement, Primary school children, School lunch, Social justice theory, Survey

\section{Introduction}

Even though the death rate of children under the age of five has dropped globally by more than fifty percent since 1990, almost 19,000 children still die daily from causes that are preventable [1]. Research indicates that poverty is the most important factor contributing to this significant death rate, even in some of the wealthiest of countries [2-6]. The deleterious effects of poverty on children has been well documented in various areas of study, such as education [7-14], physical health [15-17], mental health [18], cognitive development [19-22], and social skills [23].

One may argue that such findings have serious implications for developing countries, for example UNICEF [22] estimates that approximately 146 million children in such countries are underweight and suffer from chronic hunger. The effects of poverty on children in South Africa are no exception since almost 40 percent live in the poorest of families [24]. However, due to the proliferation of literature and studies on child poverty in South Africa, it is necessary to focus on a topic that has not received much attention over the past decade, namely the association between school lunch and achievements in childhood literacy. While several South African studies have confirmed that children from low socioeconomic (SES) families have poorer academic success than children from higher SES backgrounds [25-27], there is a dearth of literature on the effects of nutrition on the literacy achievements of children.

The need for such a study in South Africa is motivated by the findings of several global studies, which show that achievements in literacy during childhood are affected by SES [28-35]. This finding has been corroborated by few studies conducted in South Africa [36] but none of them have specifically focused on school lunch and achievements in literacy. In the context of this study 'school lunch' refers to the child participants having lunch to eat when they were at school, irrespective of its nutritional value. 'Literacy' is viewed beyond the ability to read and write to include the ability to think critically about both oral and written language, competency, knowledge and skills [37-40].

\section{Theoretical Perspective}

The social justice theoretical framework is imperative in understanding the relationship between school hunger and the literacy achievement of children. Social justice theory highlights the social injustices that exist in society that often lead to the oppression and unequal opportunities, which children may be exposed to often compromising their dignity and potential to succeed in life [41-45]. The author supports the view of Weaver-Hightower [46] who contend that food and hunger are major social justice issues in schools because of their cultural and political connotations. Studies have shown that the lack of nutritional food and hunger are very common amongst particular children and communities [47,48]. Children from these communities also bear the brunt of social stigma, especially when they have to stand in line to receive food hampers at their schools [49]. Social justice theorists postulate that all children should be provided with fair and equal opportunities to make certain that they succeed in life [50]. In the context of this study, this would mean that all children should be provided with a nutritious school lunch to ensure that they have equal opportunities to achieve some level of success in literacy [51-54].

\section{Method}

\section{Data collection}

Data was collected through a survey which quantified the number of children who took lunch to school. There were three items in the survey about school lunch that the learners could respond to, namely: I bring my own food to school, I buy food at school, or I sometimes go hungry at school. These items served as independent variables in the study. Only those independent groups, where significant differences were found, will be discussed. The dependent variables are the five literacy tests written by the learners.

"Corresponding Author: Prof. Jace Pillay, South African Research Chair in Education and Care in Childhood, Faculty of Education, University of Johannesburg, Room GNA 119, Robert Sobukwe Building, Soweto Campus (SWC), Chris Hani Road, Soweto, 1809, South Africa, Tel: +27(0)11 5595063; E-mail: jacep@uj.ac.za

Citation: Pillay J (2017) Is School Lunch Connected to Literacy Achievement in Primary School Children? A South African Perspective. Int J Psychol Behav Anal 3: 125. doi: https://doi.org/10.15344/2455-3867/2017/125

Copyright: () 2017 Pillay. This is an open-access article distributed under the terms of the Creative Commons Attribution License, which permits unrestricted use, distribution, and reproduction in any medium, provided the original author and source are credited. 
The results of these five tests were initially captured in Excel. The tests were:

1. Non-word spelling (30 B items)

2. Reading fluency (8 C items)

3. Spelling - type sounded word correctly ( $25 \mathrm{D}$ items)

4. Word spelt correctly (30 E items)

5. Most likely real word (24 F items)

Each of these tests were analyzed separately by coding 1 as correct and 0 as incorrect. This data was then transferred into SPSS 22.0 for statistical testing. Actual details of the tests can be accessed from DoIT-Profiler (2015), http://www.doitprofiler.net. The reliability and validity of the tests have been well established over a 20 year period of extensive research (Do-It-Profiler, 2015).

\section{Participants and setting}

The sample used in this study was obtained from a previously disadvantaged black school located in Orlando East, Soweto. Soweto is an urban settlement in South Africa that was established in the 1930's by the Apartheid government as a means to separate Blacks from Whites (South African History Online, http://www.sahistory.org. $\mathrm{za} /$ places/soweto). During the apartheid years, the lives of people in Soweto were characterized by abject poverty, segregation and inequity. Often public schools were in an appalling condition providing an extremely poor quality of education. The school involved in this study was no exception. Even though the situation in this particular school has improved since the advent of democracy, change has been very slow. The participants were 160 primary school children from a school in the Soweto Township of Johannesburg, South Africa (Males= 93 females $=67$, age range 12 to 14 ) (Table 1). Of these, $94(58.75 \%$ ) self-reported taking their own lunch to school, 54 (33.75\%) reported buying their lunch at school, while $12(7.5 \%)$ indicated that they were sometimes hungry at school.

\begin{tabular}{|l|l|l|l|}
\hline Category & N & Percentage & \\
\hline Gender & 160 & & 100 \\
\hline Males & 93 & 58.1 & \\
\hline Females & 67 & 41.9 & \\
\hline $\begin{array}{l}\text { Where does your lunch at school } \\
\text { come from? }\end{array}$ & \multicolumn{4}{|l|}{} \\
\hline Bring own lunch & 94 & 58.75 & \\
\hline Buy it at school & 54 & 33.75 & \\
\hline Sometimes go hungry & 12 & 7.5 & \\
\hline
\end{tabular}

Table 1: Participant demographics.

\section{Statistics}

Descriptive statistics were used to quantify the number of participants who took their own food to school, the number who bought food at school, and the number who were sometimes hungry. The five literacy tests mentioned above served as dependent variables in this study. These five tests formed an integrated multivariate factor, which was named "combined learner profiler literacy score." Testing for significant differences between independent variables were facilitated by first testing the multivariate factor using a suitable test and when any significant difference was found at this level the individual tests were tested at the univariate level to see which of the five tests was responsible for the difference between the independent groups. As four of the five tests were negatively skewed the researcher made use of non-parametric procedures at the univariate level.

\section{Ethical considerations}

Ethical clearance for conducting this study was granted by the Ethics Committee of the Faculty of Education at a university in Johannesburg, South Africa. Consent for the study was provided by the school principal, school management team, and parents of the learners. Additionally, each learner assented to participate in the study. To ensure confidentiality names of the participants and the school have been omitted.

\section{Data analysis}

Data was analyzed descriptively and also comparatively to determine any relative differences in literacy achievement between learners who did not take lunch to school and peers from same grades and classes who usually had lunch at school. Scores on four of the five literacy tests were positively skewed and non-parametric analysis (Mann-Whitney U-test; Wilcoxon test) were preferred for the group comparisons.

\section{Results and Discussion}

Data was analyzed descriptively and also comparatively to determine any relative differences in literacy achievement between learners who did not take lunch to school and peers from same grades and classes who usually had lunch at school. Scores on four of the five literacy tests were positively skewed and non-parametric analysis (Mann-Whitney U-test; Wilcoxon test) were preferred for the group comparisons.

The data in Table 2 shows that learners who sometimes do not have lunch obtained statistically significantly lower marks on the combined learner profiler tests than did learners who had some form of lunch provided. This is probably due to socio-economic circumstances where the poorer learners sometimes go hungry at school as the physiological need to eat and obtain energy goes unsatisfied in the poorer learners. The mean scores obtained are shown in figure 1.

\begin{tabular}{|c|c|c|c|c|c|c|c|}
\hline Test & Group & Mean & ANOVA & \multicolumn{4}{|c|}{ Dunnett T3 } \\
\hline (p-value) & & & & & 1 & 2 & 3 \\
\hline \multirow{3}{*}{$\begin{array}{l}\text { Combined } \\
\text { literacy } \\
\text { test }\end{array}$} & $\begin{array}{l}\text { Bring own } \\
\text { lunch }\end{array}$ & 57.38 & \multirow[t]{3}{*}{$0.000^{* *}$} & 1 & & - & ** \\
\hline & $\begin{array}{l}\text { Buy it at } \\
\text { school }\end{array}$ & 56.45 & & 2 & - & & ** \\
\hline & $\begin{array}{l}\text { Sometimes } \\
\text { go hungry }\end{array}$ & 42.60 & & 3 & ** & ** & \\
\hline
\end{tabular}

Table 2: Where does your lunch at school come from? Significance of differences between the three sources of school lunch groups with respect to the combined literacy tests.

${ }^{* *}=$ Statistically significant at the $1 \%$ level $(\mathrm{p}<0.01)$

The Mann-Whitney $\mathrm{U}$ test and the Wilcoxon test was used to determine which of the 5 learner profiler tests were responsible for this difference in the combined learner profiler scores. Only those tests where differences were found are displayed in Table 3.

There were only significant differences in tests $\mathrm{D}, \mathrm{E}$ and $\mathrm{F}$ and hence the Mann-Whitney U-test and Wilcoxon test as produced by SPSS 22.0 are given in Table 4 . 


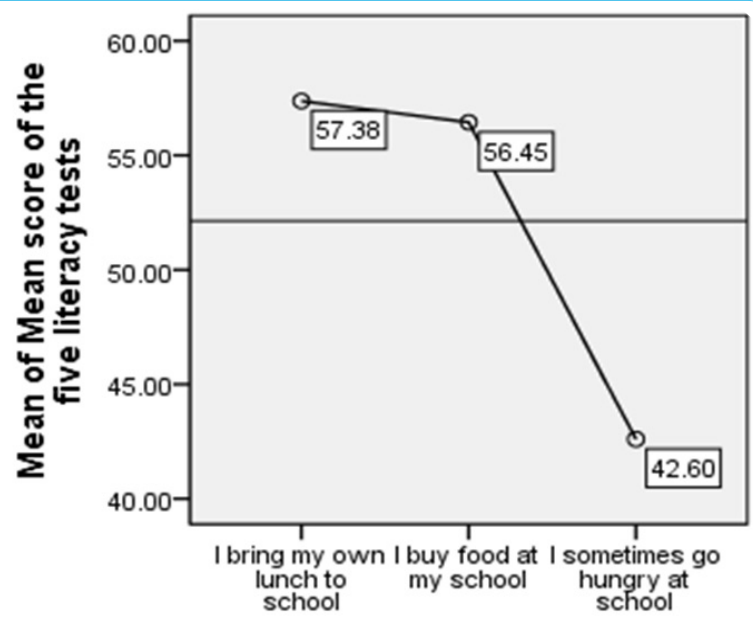

A20. Where does your lunch at school come from?

Figure 1: Line graph showing the combined literacy means for the three source of school lunch groups.

\begin{tabular}{|l|l|l|l|l|}
\hline & Null Hypothesis & Test & Sig. & Decision \\
\hline 3 & $\begin{array}{l}\text { Percentages of } \\
\text { sound texts correct } \\
\text { (D) is the same } \\
\text { across categories of } \\
\text { A20. Where does } \\
\text { your lunch at school } \\
\text { come from? }\end{array}$ & $\begin{array}{l}\text { Independent- } \\
\text { Samples Kruskal- } \\
\text { Wallis Test }\end{array}$ & $.002^{* *}$ & $\begin{array}{l}\text { Reject } \\
\text { the null } \\
\text { hypothesis. }\end{array}$ \\
\hline 4 & $\begin{array}{l}\text { Percentages of the } \\
\text { correct word (E) } \\
\text { is the same across } \\
\text { categories of A20. } \\
\text { Where does your } \\
\text { lunch at school } \\
\text { come from? }\end{array}$ & $\begin{array}{l}\text { Independent- } \\
\text { Samples Kruskal- } \\
\text { Wallis Test }\end{array}$ & $.002^{\star *}$ & $\begin{array}{l}\text { Reject } \\
\text { the null } \\
\text { hypothesis. }\end{array}$ \\
\hline 5 & $\begin{array}{l}\text { Percentages of } \\
\text { most likely real } \\
\text { word-Word choice } \\
2 \text { (F) is the same } \\
\text { across categories of } \\
\text { A20. Where does } \\
\text { your lunch at school } \\
\text { come from? }\end{array}$ & $\begin{array}{l}\text { Independent- } \\
\text { Samples Kruskal- } \\
\text { Wallis Test }\end{array}$ & $.007^{* *}$ & $\begin{array}{l}\text { Reject } \\
\text { the null } \\
\text { hypothesis. }\end{array}$ \\
\hline
\end{tabular}

Asymptotic significances are displayed. The significance level is .050. Table 3: The hypotheses test summary for the five learner profiler tests. ${ }^{* *}=$ Statistically significant at the $1 \%$ level $(\mathrm{p}<0.01)$.

\begin{tabular}{|l|l|l|l|}
\hline & $\begin{array}{l}\text { Percentages } \\
\text { of sound texts } \\
\text { correct (D) }\end{array}$ & $\begin{array}{l}\text { Percentages } \\
\text { of the correct } \\
\text { word (E) }\end{array}$ & $\begin{array}{l}\text { Percentages of } \\
\text { most likely real } \\
\text { word-Word } \\
\text { choice 2 (F) }\end{array}$ \\
\hline Mann-Whitney U & 221.500 & 222.500 & 271.000 \\
\hline Wilcoxon W & 299.500 & 300.500 & 349.000 \\
\hline Z & -3.423 & -3.430 & -2.958 \\
\hline Sig. (2-tailed) & .001 & .001 & .003 \\
\hline Effect size & 0.33 & 0.33 & 0.29 \\
\hline $\begin{array}{l}\text { a. Grouping Variable: A20. Where does your lunch at school come } \\
\text { from? }\end{array}$
\end{tabular}

Table 4: Non-parametric test values for test $\mathrm{D}, \mathrm{E}$ and $\mathrm{F}$ regarding group 1 (bring my own lunch) and group 3 (sometimes go hungry).

${ }^{*}=$ Statistically significant at the $1 \%$ level $(\mathrm{p}<0.01)$

Effect size $-r=0.10-0.29$ small; $r=0.30-0.49 ;$ moderate; $r=0.5+$ large
The data in Table 4 show that those learners who bring their own lunch to school (Group 1) differ statistically significantly from those who sometimes go hungry regarding the sound text correct test (D), the correct word (E) and the most likely real word (F). Tests D and E have the highest effect size namely 0.33 and hence these two would be the most important in explaining the variance present in the test scores. There were also statistically significant differences present between groups 2 (those who buy lunch at school) and group 3 (those who sometimes go hungry) and these results are shown in Table 5.

\begin{tabular}{|c|c|c|c|}
\hline & $\begin{array}{l}\text { Percentages } \\
\text { of sound texts } \\
\text { correct (D) }\end{array}$ & $\begin{array}{l}\text { Percentages } \\
\text { of the correct } \\
\text { word (E) }\end{array}$ & $\begin{array}{l}\text { Percentages } \\
\text { of most likely } \\
\text { real word- } \\
\text { Word choice } \\
2(\mathrm{~F})\end{array}$ \\
\hline Mann-Whitney U & 133.500 & 127.000 & 192.000 \\
\hline Wilcoxon W & 211.500 & 205.000 & 270.000 \\
\hline $\mathrm{Z}$ & -3.175 & -3.291 & -2.210 \\
\hline Sig. (2-tailed) & $.001^{\star *}$ & $.001^{\star *}$ & $.027^{\star}$ \\
\hline Effect size & 0.39 & 0.41 & 0.27 \\
\hline \multicolumn{4}{|c|}{$\begin{array}{l}\text { a. Grouping Variable: A20. Where does your lunch at school come } \\
\text { from? }\end{array}$} \\
\hline \multicolumn{4}{|c|}{$\begin{array}{l}\text { Table 5: Non-parametric test values for test } \mathrm{D}, \mathrm{E} \text { and } \mathrm{F} \text { regarding group } 2 \\
\text { (buy lunch at school) and group } 3 \text { (sometimes go hungry). } \\
{ }^{*}=\text { Statistically significant at the } 5 \% \text { level }(\mathrm{p}>0.05 \text { but } \mathrm{p}<0.01) \\
\text { ** Statistically significant at the } 1 \% \text { level }(\mathrm{p}<0.01) \\
\text { Effect size }-\mathrm{r}=0.10-0.29 \text { small; } \mathrm{r}=0.30-0.49 ; \text { moderate; } \mathrm{r}=0.5+\text { large }\end{array}$} \\
\hline
\end{tabular}

The data in Table 5 indicated that those learners who sometimes go hungry at school (G3) differ statistically significantly in sound text correct (D), correct word (E) and most likely real word (F) from those learners who buy lunch at school (G2). The best predictor was the correct word (E) test followed by D and F.

Using analyses from both Tables 4 and 5 one could also conclude that it is the learners who sometimes go hungry who perform most poorly in tests $\mathrm{D}, \mathrm{E}$ and $\mathrm{F}$ and the physiological need of hunger probably influences the ability to concentrate in school and in tests to a larger extent than those learners who have some source of food. Learners who bring their own food to school (group1) and those who buy it at school (group 2) do not differ in the three learner profiler tests. In addition, as one can compare effect sizes directly with one another, it can be seen that the most important predictor in the three tests (D, E and F) was test $\mathrm{E}$ as it had the highest effect size in both the difference between groups 1 and 3 and 2 and 3 . As the largest effect size of 0.4 was between those who buy food at school (G2) and those who go hungry (G3) one could also possibly conclude that the difference is due to financial circumstances as those who can buy food can afford it while those who go hungry cannot afford to buy food. Learners who bring food to school are also probably better off financially or have the means to prepare their own school lunch.

\section{Discussion and Recommendations}

The number of children $(7.5 \%)$ who did not have lunch at school was relatively small in the sample that was used in this particular study but the findings still indicated that these children performed more poorly in literacy tasks as compared to the other children who ate lunch at school. This finding corroborates previous studies which found that children who do not have school lunch perform more poorly in literacy tasks as compared to those children who take lunch to school $[55,56]$. 
Citation: Pillay J (2017) Is School Lunch Connected to Literacy Achievement in Primary School Children? A South African Perspective. Int J Psychol Behav Anal 3: 125. doi: https://doi.org/10.15344/2455-3867/2017/125

Page 4 of 5

However, it must be emphasized that this association is certainly not meant to insinuate a causal relationship between school lunch and poor literacy achievement amongst children since this was a small correlational pilot study limited to one school. Nonetheless, based on the findings there are some important recommendations that should be considered in order to improve the situation of children affected by school hunger.

Firstly, government should work collaboratively with community and religious based organizations to provide nutritious school meals for children who cannot afford to take lunch to school. Research has indicated that children who live in poverty usually experience hunger and this impacts negatively on their academic achievement and future economic prosperity $[57,58]$. In this way the cycle of poverty is constantly perpetuated and the poor remain poor. From a social justice perspective one would emphasize the importance of eradicating this cycle of poverty through systemic interventions and support. Secondly, schools should be instrumental in educating children out of poverty $[59,60]$ through the integration of nutrition as an essential component of early childhood education and care and development programmes [1]. Thirdly, government and relevant stakeholders should strategically integrate stimulation interventions into early childhood programmes to counter the effects of hunger on children's literacy development. Lastly, it is necessary to be cognisant of the connotations that food imposes on the identity and culture of people, for example, poor people are identified by the type of food they eat [46]. Undoubtedly the implementation of the above recommendations would promote social justice and in the process enhance the potential of children from poor families to succeed in life.

\section{Limitations and Conclusion}

The results need to be interpreted with caution, since a major limitation was the small sample size and the fact that it was conducted in only one school. As such, the results may not be representative of school lunch and achievements in literacy for all children in Soweto, or in South African schools generally. Also more details on the socioeconomic status of the participants should have been included since children not eating school lunch could be due to other reasons, for example, children not liking the food their parents give rather than them not having money or social help. Furthermore, a longitudinal study on the impact of school lunch on literacy achievement is most likely to shed light on the early and later childhood experiences of children. However, it must be emphasised that there are other possible sources of low academic achievement such as intelligence levels and the motivation to study. So in future studies it would be useful to measure and control the IQ levels and other variables important for school achievement. Despite the limitations, the findings serve as a useful pilot study to warrant the need for further in-depth research on the impact of school lunch on the literacy achievement of children. Finally, it is hoped that findings from the study might support social justice initiatives to address educational disadvantage among children who experience poverty [51-54,61,62].

\section{Competing Interests}

The authors declare that he has no competing interests.

\section{Funding}

This work is based on the research supported by the South African Research Chairs Initiative of the Department of Science and
Technology and National Research Foundation of South Africa'. South African Research Chair: Education and Care in Childhood: Faculty of Education: University of Johannesburg South Africa. Grant Number: 87300 .

\section{References}

1. Save the Children (2013) Food For Thought: Tackling child malnutrition to unlock potential and boost prosperity. London: Save the Children.

2. Huston AC (2011) Children in poverty: Can public policy alleviate the consequences? Fam Matters 87: 13-26.

3. O'Connor A (2001) Poverty knowledge: Poverty knowledge, Princeton, Princeton University Press.

4. Quigley WP (2003) Ending poverty as we know it. Philadelphia: Temple University Press.

5. Kahn AJ, Kamerman SB (2002) Social exclusion: A better way to think about childhood deprivation? In Kahn AJ, Kamerman SB (Eds.), beyond child poverty: The social exclusion of children, (pp. 11-36). Institute for Child and Family Policy at Columbia University; New York.

6. Huston AC, Bently AC (2010) Human development in societal context. Ann Rev Psychol 61: 411-437.

7. Ahmar F, Anwar E (2013) Socioeconomic status and its relation to academic achievement of higher secondary school students. IOSR Journal of Humanities and Social Sciences 13: 13-20.

8. Bergeson T (2006) Race, poverty and academic achievement.

9. Drummond K, Stipek D (2004) Low income parent's beliefs about their role I children's academic learning. The Elementary School Journal 104: 197213.

10. Khan J, Jemberu A (2002) Influence of family socio economic status on educational and occupational aspirations of high and low achieving adolescents. J Com Guid Res 19: 113-118.

11. Lacour M, Tissington LD (2001) The effects of poverty on academic achievement. Educational Research and Reviews 6: 522-527.

12. Rothman (2003) The changing influence of socio economic status on students' academic achievement. Recent evidence from Australia. Paper presented at the annual meeting of the American education Research Association, Chicago.

13. Rowan B, Cohen DK, Raudenbush SW (2004) Improving the educationa outcomes of students in poverty through multidisciplinary research and development.

14. Sirin SR (2005) Socioeconomic status and academic achievement: A metaanalytic review of research. Review of Educational Research 75: 417-453.

15. Egeland GM, Pacey A, Cao Z, Sobol I (2010) Food insecurity among inuit pre-schoolers. Nunavut Inuit Child Health Survey, 2007-2008. Canadian Medical Association Journal, Research.

16. Jomma LH, McDonnell E, Probart C (2011) School feeding programs in developing countries: Impacts on children's health and educational outcomes. Nutr Rev 69: 83-98.

17. Levine S (2008) School lunch politics. The surprising history of America's favourite welfare program. Princeton, NJ: Princeton University Press.

18. Weinreb L, Wehler C, Perloff J, Scott R, Hosmer D, et al. (2002) Hunger. It's Impact on Children's Health and Mental Health. Pediatrics 110: 1-9.

19. Grantham Mcgregor S, Cheung YB, Cueto S, Glewwe P, Richter L, et al. (2007) Development potential in the first 5 years for children in developing countries. The Lancet 369: 60-70.

20. Prado E, Dewey K (2012). Insight nutrition and brain development in early life. AT\&T Technical Brief.

21. Sanchez A (2009) Early Nutrition and cognitive Achievement in Pre- School Children in Peru. Working paper 57. Oxford: Young Lives.

22. UNICEF (2012) State of the World's Children (2012), New York: The United Nations.

23. Jyoti DF, Frorngillo EA, Jones SJ (2005) Food Insecurity affects school children's academic Performance, Weight gain, Social skills. American Society for Nutrition. 
Citation: Pillay J (2017) Is School Lunch Connected to Literacy Achievement in Primary School Children? A South African Perspective. Int J Psychol Behav Anal 3: 125. doi: https://doi.org/10.15344/2455-3867/2017/125

Page 5 of 5

24. SAHRC \& UNICEF (2014) Poverty traps and social exclusion among children in South Africa, Pretoria, SAHRC.

25. Lam D, Ardington C, Leibbrandt M (2011) Schooling as a lottery: racial differences in school advancement in urban South Africa. Journal of Development Economics 95: 121-136.

26. Spaull N (2013) Poverty \& privilege: Primary school inequality in South Africa. International Journal of Educational Development 33: 436-447.

27. Van der Berg S (2007) Apartheid's enduring legacy: inequalities in education. Journal of African Economies 16: 849-880.

28. Baker $L$ (2003) The role of parents in motivating struggling readers. Reading and Writing Quarterly, Overcoming Learning Difficulties 19: 87106.

29. Baker L, Scher D (2002) Beginning readers' motivation for reading in relation to parental beliefs and home reading experiences. Reading Psychology 23: 239-269.

30. Chow BWY, McBride-Chang C (2003) Promoting language and literacy development through parent-child reading in Hong Kong pre-schoolers Early Education and Development 14: 233-248.

31. Jordan GE, Snow CE, Porche MV (2000) Project EASE: the effect of family literacy project on kindergarten students' early literacy skills. Reading Research Quarterly 35: 524-546.

32. Saint-Laurent L, Giasson J (2005) Effects of a family literacy program adapting parental intervention to first graders' evolution of reading and writing abilities. Journal of Early Childhood Literacy 5: 253-278.

33. Saracho ON (2002) Family literacy: exploring family practices. Early Child Development and Care 172: 113-122.

34. Stainthorp R, Hughes D (2000) Family literacy activities in the homes of successful young readers. Journal of Research in Reading 23: 41-54.

35. Turner JC (1995) The influence of classroom contexts on young children's motivation for literacy. Reading Research Quarterly 30: 410-441.

36. Howie S, Van Staden S, Tshele M, Dowse C, Zimmermann L (2012) PIRLS 2011: South African children's reading literacy achievements, Summary Report, Pretoria: University of Pretoria.

37. Dubin F, Kuhlman NA (1992) The dimensions of cross-cultural literacy. In Dubin F \& Kuhlman NA (Eds.), Cross-cultural literacy: Global perspectives on reading and writing ( $\mathrm{v}-\mathrm{x})$ : Englewood Cliffs, NJ: Regents/Prentice hall.

38. Foley BE (1994) The development of literacy in individuals with severe congenital speech and motor impairments. In K.G. Butler (Eds.), Severe communication disorders: Intervention strategies (183-199): Gaitherburg, MD: Aspen.

39. Hiebert EH (1991) Introduction. In E.H. Hiebert (Eds.), Literacy for a diverse society: Perspectives, practices, and policies, (pp. 1-6): New York: Teachers College Press.

40. Langer JA (1991) Literacy and schooling: A socio-cognitive perspective. In E.H. Hiebert (Eds.), Literacy for a diverse society: Perspectives, practices, and policies, (pp.1-6): New York: Teachers College Press.

41. Leatham CP (2005) The lived experiences of adolescent learners from child-headed-Families in the Northern Free State. Master's Dissertation. Johannesburg: University of Johannesburg.

42. Pillay J, Nesengani RI (2006) The educational challenges facing early adolescents who head families in rural Limpopo Province. Education as Change 10: 131-147.

43. Lethale PS (2008) The resilience of adolescents from adolescent- headed families within the school context. Unpublished Master's Dissertation. Johannesburg: University of Johannesburg.

44. Pillay J (2014b). Challenges educational psychologists face working with vulnerable children in Africa, in T. Corcoran, (Eds.), Psychology in Education. Australia: Sense Publishers.

45. Shriberg D, Wynne ME, Briggs A, Bartucci G, Lombardo AC (2011) Schoo Psychologist: Perspectives on social justice. School Psychology Forum5: 37-53.

46. Weaver-Hightower MB (2011) Why education researchers should take school food seriously. Educational Researcher 40: 15-21.
47. Anyon J (2005) What counts as educational policy? Notes towards a new paradigm. Harvard Educational Review 75: 65-88.

48. Patel, R. (2007). Stuffed and starved: Markets, power and the hidden battle for the world food system. London: Portobello Books.

49. Ludvigsen A, Scott S (2009) Real kids don't eat quinche. What food means to children. Food, Culture and Society 12: 417-436.

50. Pillay J (2014a) Advancement of children's rights in Africa: A social justice framework for school psychologists. School Psychology International 35 225-240.

51. Benedetto AE, Olisky T (2001) Biracial youth: The role of the schoo counselor in racial identity development. Professional School Counselling 5: 66-71.

52. Smith $A B$ (2002) Interpreting and supporting participation rights: Contributions from sociocultural theory. International Journal of Children's Rights 10: 73-88.

53. Stainton Rogers W (2004) Promoting better childhoods: Constructions of child's concern. In M.J.Kehily (Eds.), an introduction to childhood studies (pp 125-144): Maidenhead: Open University Press.

54. Bartolo PA (2010) Why school psychology for diversity? School Psychology International 31: 567-580.

55. Kursmark M, Weitzman M (2009) Recent findings concerning childhood food insecurity. Current Opinion in clinical Nutrition and Metabolic Care 12: 310-316.

56. Winicki J, Jemison K (2003) Food insecurity and Hunger in the Kindergarten Classroom. It's Effect on learning and growth. Contemporary Economic Policy, 21: 145-157

57. Save the Children (2012) A life free from hunger. Tackling child malnutrition. London: Save the Children.

58. World Bank (2006) Repositioning Nutrition as Central to Development. A strategy for large scale action. Washington: The World Bank.

59. Mouton N, Strydom G (2013) Critical challenges of the South African school system. International Business and Economics Research Journal 12: 286300.

60. Thomas M (2012) Success can be a matter of principal. Mail \& Guardian 17 August.

61. Reddy V, Prinsloo C, Visser M, Arends F, Winnaar L, et al. (2012) Highlights from TIMSS 2011: The South African perspective, Pretoria: HSRC

62. South African History Online, An Overview of Soweto.

Int J Psychol Behav Anal

ISSN: 2455-3867 